\title{
Itsensä kehittäminen johtajien kertomuksissa
}

\author{
VIRPI TÖKKÄRI \& JUHA PERTTULA
}

\begin{abstract}
Artikkeli perustuu tutkimukseen ${ }^{1}$, jossa tarkastellaan tietoisen itsensä kehittämistä analysoimalla kahden johtajan kertomuksia. Narratiivinen lähestymistapa sitoi johtajien itsensä kehittämisen kertomuksiksi, joissa ovat läsnä humanistinen itseksi tuleminen, eksistentiaalinen persoonan valitseminen ja kulturalistinen jaetuissa merkityksissä eläminen. Itsenä kehittämisen merkityksissä yksilöllinen valinnanvapaus ja omaehtoinen, autonominen kehittyminen nivoutuvat yhteisölliseen elämään.
\end{abstract}

Ihmisenä oleminen on muuttumista. Ihminen ei voi sille mitään, mutta hän voi pyrkiä kehittymään haluamaansa suuntaan. Kuvatussa tutkimuksessa tarkastellaan tietoista itsensä kehittämistä. Valitsimme johtajuuden kontekstiksi, koska johtajalla on parhaat mahdollisuudet vaikuttaa vuorovaikutukseen työpaikalla (Toskala 2000).

Johtajuusnäkökulman valintaan vaikutti myös se, että johtajien itsensä kehittäminen on yksi trendi tieteellisessä johtamiskeskustelussa. Salojärvi (2006) ennustaa, että kyky itsensä johtamiseen nousee johtajien avainosaamiseksi, koska ilman sitä muu osaaminen ei toteudu. Juuti (2005) pohtii itsensä kehittämisen teemaa toivon johtamisen käsitteellä. Toivon johtaminen tarkoittaa uskoa siihen, että ihminen oppii jatkuvasti uutta ja pyrkii kasvamaan henkisesti. Saarinen ja Aalto-Setälä (2007) toivovat työpaikoille enemmän tunneosaavaa johtamista. Siihen voitaisiin päästä siten, että esimiehet lisäisivät itsetuntemustaan ja opettelisivat ymmärtämään paremmin tunne-elämäänsä.

Käsiteviidakosta valitsimme tutkimuksen avainkäsitteeksi itsensä kehittämisen. Se sopii avoimena ja kattavana yksilön kehittymisen aihepiirin yleiskäsitteeksi. Itsensä kehittäminen voi sisältää sekä itsensä johtamista että itsetuntemuksen lisäämistä. Se voi merkitä paitsi konkreettista tietojen ja taitojen opettelua myös abstraktimpaa henkistä kasvua.

Tutkimuksen taustalla on ajatus johtamisesta psykologisena työnä. Sitä voi nimittää myös ihmissuhdetyöksi ja psykososiaaliseksi työksi (ks. Syväjärvi, Perttula, Stenvall, Majoinen \& Vakkala
2007). Näkemyksen mukaan johtamistyö toteutuu vuorovaikutuksena ihmisten kesken (Perttula 2006). Vuorovaikutusta on myös itsensä kanssa, mikä toteutuu itsensä johtamisena, yksilön kehittymisenä ja itsensä kehittämisenä.

Kun johtaminen ymmärretään ihmissuhdetyönä, on sen tutkimiseksi perusteltua asettaa niin sanottu johtamistyön ontologinen kysymys (Syväjärvi ym. 2007). Se tarkoittaa johtamistyön perustana olevan ihmiskäsityksen hahmottamista ja, toisin päin ajateltuna, erilaisiin ihmiskäsityksiin pohjautuvan johtamistyön luonnostelua. Johtamistyön ontologinen kysymys liittää johtamisen osaksi aikuiskasvatusta, koska ihmiskäsitys antaa suuntaa ihmisenä kehittymisen ymmärtämiselle ja johtamisen kontekstina on työelämä eli "aikuisten valtakunta".

Itsensä kehittäminen on käsite, jonka juuret ovat humanistisessa traditiossa. Itsensä kehittäminen tarkoittaa itsenään kehittymistä, joka ilmenee itsetuntemuksen kirkastumisena ja henkisenä kasvuna kohti omaa itseä (Perttula 2009). Humanistinen traditio heijastelee essentialistista ihmiskäsitystä, joka asettaa ihmisenä kehittymiselle ihanteet ja normit (ks. Kannisto 1994). Johtamistyöhön sovellettuna essentialistinen ihmiskäsitys ilmenee ihanteiden johtamisena (Perttula 2006). Samat ihanteet koskevat johdettavia ja johtajaa itseään.

Tässä kuvatussa tutkimuksessa tarkastellaan johtajien itsensä kehittämistä humanistista traditiota, ja samalla essentialistista ihmiskäsitystä, vasten. Kulturalistinen ja eksistentiaalinen ihmiskäsitys ovat essentialismin ohella länsimaisen elä- 
mänmuodon keskeisiä ihmiskäsitysten prototyyppejä, niiden mallikuvia (Kannisto 1994). Kulturalistisen ihmiskäsityksen kannalta johtajien itsensä kehittäminen toteutuu vuorovaikutuksena itsen ja työyhteisön välillä. Johtaja "ihmistyy" elämällä työpaikan vuorovaikutussuhteissa ilman tarvetta olettaa itselleen essentiaa - olemusta - jota hän työssään määrittelisi ja toteuttaisi. Eksistentiaalinen ihmiskäsitys painottaa johtajan yhtäaikaista yksityistä olemista ja kanssaolemista toisten kanssa. Johtajien itsensä kehittämisessä keskeisiksi nousevat valitsemisen kysymykset ja kyky johtaa valitsemista (Perttula 2006).

Itsensä kehittämisen aihepiiri on ajankohtainen myös empiirisessä johtamistutkimuksessa. Itsensä kehittäminen sisältää lähtöoletuksen, että itseään kehittävä ihminen on tietoinen ajatuksistaan ja että hän pystyy jollakin tavoin kontrolloimaan psyykkistä elämäänsä. Aihealueen tutkimuksissa onkin korostunut nimenomaan itsensä ymmärtäminen ja psyykkinen hallinta, toisin sanoen itsensä johtaminen (ks. Neck \& Houghton 2006). Åhman (2003) on tutkinut teemaa oman mielen johtamisen käsitettä käyttäen. Hänen johtopäätöstensä mukaan oman mielen johtamisella on suuri merkitys yksilön menestymiselle työelämässä, minkä vuoksi tätä taitoa on tärkeää kehittää. Itsensä johtamisen on myös havaittu vaikuttavan myönteisesti muiden ymmärtämiseen ja diversiteettiin sopeutumiseen (Mirvis 2008).

Itsensä kehittäminen liittyy empiirisenä tutkimusteemana myös hiljaisen tiedon ja toiminnan suhteen pohdintaan. Päätösten tekeminen edellyttää johtajalta hiljaista tietoa, joka ei kehity raportteja lukemalla vaan tekemällä, kokemalla ja pohtimalla (Janson \& McQueen 2007). Kokemisen osuus johtajana kehittymisessä on merkittävä: hyväksi johtajaksi ei tulla keskittymällä itseensä ja omaan kehittymiseensä vaan toimintaan ja kokemuksista oppimiseen (Olivares, Peterson \& Hess 2007). Von Krosigkin (2007) tutkimuksen mukaan menestyksekkääksi johtajaksi kasvaminen näyttää usein alkavan jo lapsuudessa vuorovaikutustaitojen opettelulla. Kokemusten lisääntyessä johtajalle muodostuu parhaimmillaan sekä kyky toimia sopusoinnussa muiden kanssa että vahva luottamus omaan intuitioon (Von Krosigk 2007).

Johtajana kehittyminen ja itsensä kehittäminen johtajana muodostaa monitahoisen aihealueen, jossa kohtaavat niin käytännön koulutuksen ja työnteon kuin elämänhistorian ja -ymmärtämisen kysymykset. Tämän tutkimuksen tavoite on lisätä ymmärrystä siitä, mitä merkityksiä johtajat itse antavat itsensä kehittämiselle. Tarkastelemme myös, miksi itsensä kehittäminen on tavoiteltavaa ja mitä kohti se suuntautuu. Narratiivinen eli kertomuksellinen ajattelu- ja tutkimustapa soveltuu hyvin näiden merkitysten tarkasteluun. Lisäksi narratiivinen tutkimustapa on kiinnostava mahdollisuus ulottaa johtajien itsensä kehittämistä koskeva tarkastelu humanistisesta traditiosta vuorovaikutusta ja valitsemista korostaviin näkökulmiin.

\section{Narratiivinen tutkimustapa}

Narratiivisen eli kertomuksellisen tutkimustavan avulla on mahdollista hahmottaa itsensä kehittämistä ajallisesti laajana teemana. Työelämän ja johtajuuden tutkiminen narratiivisesti on yleistynyt ja sitä hyödyntävät sekä käytännön yrityskehittäjät että akateemiset tutkijat. Narratiivisen otteen yksi hyöty on, että sen avulla päästään tutkimaan työelämässä vaikuttavia tulkintatapoja, jotka ovat vain osin tiedostettuja (Aaltonen \& Heikkilä 2003).

Hyvärisen (2004) tapaan ymmärrämme kertomuksellisuuden kokemukselle analogisena: se jäsentää kokemista. Kertomus ei siis ole olemassa omaksi ilokseen ja itseään varten, vaan se pyrkii aina sanoittamaan kokemuksen (Ricœur 1997). Koska kertomukset ovat avoimia ja muokattavissa uudelleen, niiden avulla voidaan hallita menneisyyttä ja hahmotella tulevaisuutta sekä rakentaa narratiivisia identiteettejä eli minäkertomuksia (Ihanus 1999; Hyvärinen 2006). Kertomukset kantavat tapahtumille annettuja merkityksiä ja tulkintoja (Bruner 1990) ja rakentavat tulevaisuuden mahdollisuuksia (Murray 2004). Kertomukset eivät kuitenkaan tähtää vain kokemusten ymmärtämiseen ja välittämiseen. Niillä pyritään tilanteen mukaan myös vaikuttamaan, oikeuttamaan ja johtamaan (Ihanus 1999).

Narratiivinen tutkimus ei anna yhtenäistä metodista ratkaisumallia. Polkinghorne jakaa narratiivisen tutkimuksen tavat kahteen tyyppiin, joiden perustana on Brunerin mallinnus tiedonmuodostuksen jakautumisesta paradigmaattiseen eli luokitteluja tekevään ja narratiiviseen eli kertomuksia rakentavaan tietämiseen (Bruner 1990; Polkinghorne 1995). Jako kahteen analyysityyppiin pätee vain yleisellä tasolla (Erkkilä 2005). Kuvaamassamme tutkimuksessa käytettiin analyysimuotoa, jossa on molempien tyyppien tuntomerkkejä. Paradigmaattiseen tietämiseen perustuvaa analyysitapaa edustaa tehty luokittelu ja narratiivista tapaa 
lähtökohta, jossa pyrittiin alun alkaen keräämään kertomusten sijaan aiheen kuvauksia (ks. Polkinghorne 1995).

Narratiivisessa tutkimuksessa tutkimuskohteena ovat tutkijalle esitetyt kertomukset ja kertomuksissa koostettu subjektiivi-

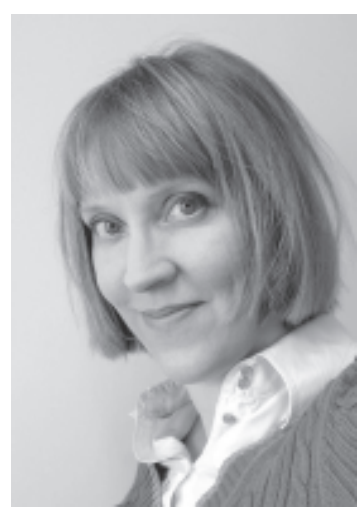

Virpi Tökkäri

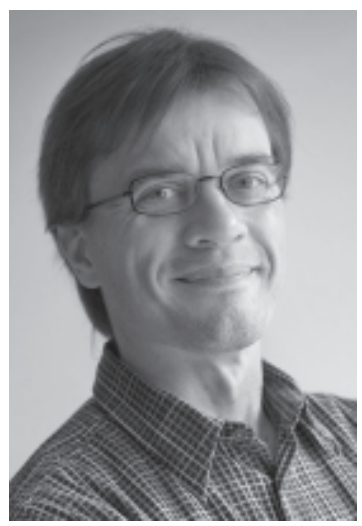

Juha Perttula suus, eivät aktuaaliset tapahtumat tai yksilön tajunnan sisällöt (Parker 2005). Konteksti on narratiivisessa tutkimuksessa tärkeä käsite, jolla voidaan viitata kertomuksen sijoittumiseen tiettyyn sosiaaliseen struktuuriin, aikaan ja paikkaan (Erkkilä 2005). Tyypittelyä tehtäessä tarkasteltiin erityisesti sitä, miten kertomukset kiinnittyvät toisten ihmisten toimintaan ja kertojan elämäntilanteeseen. Tutkimuksen toinen tärkeä käsite on toimijuus (Parker 2005). Toimijuutta tarkastellaan tulkitsemalla etenkin kertojien toiminnan omaehtoisuutta ja muiden ihmisten tai olosuhteiden vaikutusta kertojan tekoihin.

Tutkimusta varten etsittiin muutaman yhdistyksen avulla haastateltavaksi kaksi johtajaa. Haastateltavien haluttiin olevan itseään tietoisesti kehittäneitä johtotai esimiestehtävissä toimivia henkilöitä. Aseman lisäksi haastateltavien valinnan kriteerinä pidettiin valmiutta ja halukkuutta kertoa itsensä kehittämisestä. Henkilöiden sukupuolta tai ikää ei pidetty tärkeinä. Haastateltaviksi valikoitui kaksi noin 55-vuotiasta miestä. Toinen haastatelluista johti keskisuuren kaupungin liikelaitosta, toinen omaa konsernia.

Puolistrukturoitujen haastattelujen pohjana oli kysymysrunko, joka jakautui itsensä kehittämistä menneisyydessä, nykyisyydessä ja tulevaisuuden suunnitelmissa koskeviin kysymyksiin. Kysymykset muotoiltiin enimmäkseen haastateltavien vastausten mukaan. Näin oli mahdollista tarttua esiin nouseviin teemoihin ja ottaa huomioon haastateltavien kiinnostusten kohteet. Itsensä kehittämisen käsitettä ei määritelty haastateltaville etukä- teen, koska haluttiin tutkia, miten he määrittelevät käsitteen omien kokemustensa pohjalta.

Molemmat haastattelut tapahtuivat haastateltujen valitsemissa rauhallisissa tiloissa ja kestivät hieman yli tunnin. Haastattelut äänitettiin ja litteroitiin sanatarkasti. Aineisto-otteissa lyhennetyt kohdat on merkitty kolmella pisteellä ja sulkumerkeillä. Päällekkäin puhumisen merkkinä käytetään hakasulkeita ja omien lisäysten merkkinä aaltosulkeita. Lyhennykset on tehty haastateltujen anonyymiuden suojaamiseksi tai vähentämään asian toistoa. Lisäyksillä, joita on käytetty vain vähän, on pyritty selventämään puheena olevaa asiaa. Lihavoinnilla on merkitty kohdat, joihin tulkinnat erityisesti perustetaan. Leipätekstin kursivoinneilla korostetaan kertojien käyttämiä ilmaisuja, jotka ovat olleet analyysille tärkeitä.

\section{KOLME TARINATYYPPIÄ}

\section{Kertojat ja asemointivariaatiot}

Tutkimuksen tuloksina kuvataan itsensä kehittämistä kolmessa kertomuksellisessa asemoinnissa, jotka on nimetty selviytyjän, toisten tukeman ja valintojen tekijän tarinoiksi. Kertomuksen ja tarinan käsitteitä käytetään usein toistensa synonyymeinä (Hyvärinen 2006). Tässä tutkimuksessa tarinan käsitettä käytetään tarkoittamaan tarinan yleistä tapahtumakulkua eli juonta, jolloin kertomukset ovat versioita tarinasta.

Analyysin alussa aineistosta poimittiin kertomukset, joissa kertojat käyttivät itsensä kehittämisen käsitettä. Kertomukset ovat tapahtumaketjuja, joissa kertoja uudistuu tai huomaa jotain uutta ja merkityksellistä. Tällaisia kertomuksia oli kummallakin kertojalla useita. Kertomuksista jäsennettiin kolme tarinatyyppiä sen mukaan, millaiseksi toimijaksi kertojat niissä itsensä asemoivat. Tehdyt jäsennykset perustettiin aineistoon yleisten lajityyppien sijaan (ks. Hyvärinen 2006). Yksittäinen kertomus voi sisältää useita tarinatyyppejä, koska kertojan itsensä asemointi voi vaihdella juonen eri vaiheissa tai kertomusta uudelleen kerrottaessa. Kummankin haastateltavan kertomuksissa on elementtejä eri tarinatyypeistä. Tarinatyypeillä ei näin ollen tyypitellä haastateltavia, vaan niiden avulla pyritään osoittamaan itsensä kehittämisen paikantumista ja merkityksiä kertomuksissa. Tulkintoja, joihin jäsennykset perustuvat, esitellään samalla kun asemointivariaatiot kuvataan.

Kertojina on kaksi johtajaa, joista käytetään 
kertojanimiä Seppo ja Henri. Seppo on ollut virassaan liikelaitoksen johtajana vajaa kymmenen vuotta. Liikelaitoksessa työskentelee $30-40$ henkilöä. Aiemmin Seppo toimi aktiivisesti politiikassa. Hän toimii yhä erilaisissa edustustehtävissä ja seuraa tiiviisti yhteiskunnallisia tapahtumia. Henri on hoitanut yritysryvästään kymmenisen vuotta. Hänellä ei ole alaisia nykyisessä työssään. Aiemmin Henri työskenteli lähes 20 vuotta kansainvälisen suuryrityksen johtajana, mitä ennen hän oli työskennellyt yrittäjänä ja johtotehtävissä nuoresta lähtien.

\section{Selviytyjän tarina}

Ensimmäisessä tarinatyypissä kertojan kehittymisen aloittaa tai sitä vauhdittaa elämäntilanteeseen yllättäen tai vaivihkaa ilmaantuva käänne, joka voidaan kuvata kielteisenä tai myönteisenä. Valaisemme tarinatyyppiä ensin otteella Henrin haastattelusta.

Ote 1: Yks vedenjakaja sijottuu vuoteen (...), jollon mä sairastuin vakavasti (...) ja makasin letkuissa sitte puolitoista viikkoa (...) ja sinä aikana ku mietti, et olisinko mä tässä nyt heittäny henkeni tai oonks mä dialyysissä lopun ikääni, niin (...) käynnistyi sellanen prosessi, joka kesti kaksi vuotta, et mä sanouduin irti erittäin hienosta ja hyvästä työpaikastani tehdäkseni jotain sellasia asioita, jotka liittyy itsensä kehittämiseen. (Henri)

Henrille äkillinen sairastuminen on vedenjakaja eli selkeä muutoskohta elämässä - tapahtuma, jossa kehityskulku käynnistyi. Tapahtuman ulkoisen sattuman luonnetta korostaa joutuminen sairaalaan, jossa yksilön määräysvalta kehoonsa on usein vähäinen. Kertojan kehittyminen ei kuitenkaan ole tapahtuman aiheuttama vaan vain sen vaikuttama. Sairaus on kertomuksen prologi, kun varsinainen ydinkertomus muodostuu kertojan pohdinnallisesta toiminnasta. Kertomuksen funktio on tuoda toimijuus takaisin kertojalle ja luoda järjestystä hallitsemattomaan tilanteeseen (ks. Murray 2004). Kertomuksen lopussa Henri aloittaakin oman liiketoimintansa, jossa hän saa määritellä työnsä sisällön ja toteuttaa haaveitaan. Sen, että lähti kulttuurisesti hyvän työpaikan tuntomerkit täyttävästä asemastaan, Henri kertoo esimerkkinä omaehtoisesta toiminnasta, jonka hän nimeää toisin tekemiseksi. Toisintekijäksi erottautumalla kertoja määrittää itsensä kehittämisen valtavir- rasta poikkeaviksi teoiksi.

Suurten muutosten lisäksi sattumia kohdataan arkisen aherruksen lomassa. Nopeasti unohtuvien sattumusten virrasta jää toisinaan mieleen yksittäinen tapahtuma, jolloin kertomus saa selviytyjän tarinan luonteen. Seppo kertoo tällaiseksi tapahtumaksi erään pikkujoulujuhlan. Hän kuuli toisten puhuvan itseensä liittyviä asioita, jotka saivat hänet arvioimaan siihenastista johtajuuttaan sekä kertomuksen lopuksi ymmärtämään paremmin itseään ja toisia (ote 2).

Ote 2: Lähinnä se on ollu (...) sen ymmärtäminen, että jos kuvittellee että ite on niin fiksu ja mukava että kaikki tykkää, niin sen, sen niinku myöntäminen itelle, että ei se näin ole, ole niin tuota, se on niinku helepottanu tilannetta, että. (...) (Seppo)

Molemmat kertojat kertovat tapahtumien reaalista sisältöä tärkeämmäksi sen, miten he niihin suhtautuvat. Kertoja voi muokata sattuman, joka antaa ainekset taantuvaan kertomukseen, kasvavaksi ja myönteiseksi kertomukseksi. Myönteinen kertominen ei aineiston perusteella tarkoita, että kertoja kuvittelee asioiden olevan tietynlaisia, vaan johtaja käyttää sitä työvälineenä, keinona tehdä asioista helpommin käsiteltäviä ja hyväksyttävämpiä (otteet 3 ja 4).

Ote 3: (...) itelleni vaan sanonu ja yrittäny tälle porukalle sitä tuua esille, että ku tämmösiä... myllerryksiä niinku kuntayhteisö ja kaupunkiyhteisössä käyään koko ajan ja se talous niinku siellä ahistaa... niin semmonen usko, että kun yritetään olla siellä ensimmäisessä vaunussa niin se tahtoo aina kulukia se juna veturin mukana, että, että semmonen niinku myönteisesti yrittää asioita lähestyä, se muutos on kuitenki aina tapahtuva. (...) Et semmonen niinku kunnianhimo pitää olla, kuitenki. (...) (Seppo)

Ote 4: Usein käy niin et me tarvitaan semmonen kriisi et me pysähdytään ja osataan nähdä niinku sen päivittäisen tekemisen ja arjen tekemisen yläpuolelle... Näin, näin muodoin, kriisit on, ne on valepukusia enkeleitä, ne on siunauksia, jos ne vaan osaa sillä tavalla nähdä. Mut mä nimenomaan haluan painottaa sitä, et kysymys on juuri siitä, et itse voi vaikuttaa. (Henri)

Myönteinen kertominen on sekä itselle puhu- 
mista että muiden vakuuttamista - siis johtamisen retorinen työkalu. Myllerrykset viittaavat arjen sattumiin, jotka tuovat jatkuvasti uusia kasvunpaikkoja. Usko ja kunnianhimo kertovat, että myönteisyys on luottamusta hankalalta näyttävien asioiden etenemiseen ja tahtoa käsitellä vaikeitakin tilanteita. Itsestä riippumattoman muutoksen hyväksyminen sekä vastuun ottaminen omista ajatuksista ja teoista antaa kertojalle mahdollisuuden olla suunnannäyttäjä. Muutoksen vastustaminen ja kehityksen eturintamasta tippuminen on vaihtoehtoisena käänteenä epämiellyttävä.

Henri sitoo me-muodolla kertomuksensa osaksi yleisesti jaettua tarinaa. Voi kuitenkin olettaa, että myönteinen kertominen saattaa olla helpompaa johtajalle kuin alaiselle. Koska ihmisillä on taipumus omaksua organisaatiorakenteisiin ennalta kirjoitetut roolit, organisaatioiden valta johtajien ja työntekijöiden identiteettien ja kertomusten muokkaajana on suuri (Carden \& Callahan 2007). Uskolle ja kunnianhimolle ei välttämättä löydy sijaa kertomuksessa, jota oman vaikutusvallan ulkopuolella olevat organisatoriset tarinat eivät vahvista.

Itsensä kehittymisen kertominen saattaakin edellyttää vahvaa kokemusta siitä, että asioihin voi itse vaikuttaa tapahtuvan muutoksen suuntaisesti. Henri huomasi nuorena kilpaurheilijana, että pystyi vaikuttamaan suorituksiinsa kirjaamalla tavoitteensa, jotka sitten saavutti tai ylitti. Tavoitteiden kirjaamisen ja niiden saavuttamisen välinen assosiaatio vahvistui myöhemmin työelämässä. Sepollakin on kokemusta vaikutusmahdollisuuksista työssään. Itsenäistä ajattelua ja toimintaa korostaen Seppo erottaa itsensä niistä, jotka uskalluksen tai tahdon puutteen vuoksi mukautuvat ja jäävät rypemään kielteisyyteen (ote 5).

Ote 5: (...) jos siihen sanoo, ettei se ihan näin oo, niin sen, sen sai sen keskustelun käännettyä toisin päin, mutta jos siihen lähit mukkaan niin kyllä sä voit siellä loassa rypeä sitten. (...) Että seki on vähän tämmönen tahto, tahtokysymys, ja sitte tämmönen uskallus, uskallus ettei niinku aina tarvi olla joojoo tai tyytyä siihen mitä toiset sannoo. (Seppo)

Selviytyjän tarinassa on samoja elementtejä kuin von Krosigkin (2007) tutkimuksen selonteoissa, joissa tarkasteltiin johtajan ominaisuuksia ja kehittymistä elämänhistorian aikana. Von Krosigkin tutkimissa johtajien kertomuksissa tyypillistä oli, että johtajat kertoivat joutuneensa tai pääs- seensä arvioimaan tekemisiään ja uskomuksiaan vaihtelevissa tilanteissa. Itsereflektion ja toisten tarkkailun avulla he olivat oppineet olemaan rehellisiä itseään kohtaan. Myös konstruoidussa selviytyjän tarinassa rehellisyys itseä kohtaan kerrotaan avainasiaksi. Tarinan sanoma on, että kertojan ei tarvitse ajatella ja tehdä niin kuin muut, vaan kertomuksen voi muokata mieleisekseen ajattelemalla ja tekemällä toisin. Passiivisen selviytyjän tarinan onkin linkityttävä aktiivisen valintojen tekijän tarinatyyppiin, jotta itsensä kehittämisen kertominen on mahdollista.

\section{Toisten tukeman tarina}

Kun kertoja sijoittuu toisten tukemaan tarinaan, hän kehittyy toisten avulla tai kanssa. Itsensä kehittäminen punoutuu työn vaatimuksiin ja sosiaaliseen toimintaan. Tässä tarinatyypissä kertoja katoaa hetkeksi intersubjektiiviseen tekemiseen, minkä jälkeen hän valintojen tekijän tarinaan asemoituen ilmestyy tulkitsemaan tapahtuneen ja kertomaan epilogin. Seppo kertoo seuraavissa otteissa edenneensä politiikassa ja työurallaan toisten osoittaman luottamuksen avulla, ilman tarkoituksellista pyrkimistään.

Ote 6: Haastattelija: Elikkä oliko se silleen, että sie oot itte tuntenu, että sie valittit sen \{politiikassa toimimisen\}?

No kyllähän mä oon tietenki kiinnostunu ollu, olin peruskiinnostunu, mutta tuotaa... sitten näissä politiikkakuvioissa varmaanki käy niin, että semmonen henkilö, joka on kiinnostunu ja uus, niin se tempastaan mukaan, jos se ei osaa sanoa että ei, niin sitä on niinku siellä sisällä. (Seppo)

Ote 7: Se miksikä mä oon semmosiin \{politiikkakuvioihin\} joutunu, lähinnä joutunu tai päässy, että mä en ite tunne itteäni kauhean kunnianhimoseksi, mutta... jotenki jos on aktivinen ja ihmiset luottaa niin... semmosissa kuvioissa niin semmoselle ihmiselle sitte aletaan kasaamaan hommia. Mutta että miten se liittyy niinkö itsensä kehittämiseen niin tuota kyllä se politiikkakuviokin tietenki sillä tavalla, että siinähän pääsee aika paljon näkemään niinku yhteiskunnan tämmösiä... lainalaisuuksia, pakko niinku mietiskellä asioita laajemmin. (Seppo)

Politiikkaan mukaan meno ei rajaudu vain elä- 
män tuomaksi sattumaksi, kuten tapahtumat selviytyjän kertomuksissa. Siinä on mukana omaakin kiinnostusta. Kiinnostus ei ehkä ole suurta innostusta, mistä kertoo sanavalinta peruskiinnostunut. Oman valinnanteon torjunta on läsnä vastauksen epäsuoruudessa ja oman kunnianhimon vähyyden maininnassa. Kertoja on toiminnan kohde, joka tempaistaan, joka joutuu, jolle kasataan ja johon luotetaan. Toisten merkitys kehitykselle ja kohteena oleminen näkyy myös siinä, miten kertoja pääsee näkemään yhteiskunnallisia toimintamalleja ja miten hänen on pakko mietiskellä asioita. Kumpikin ilmaisu merkitsee mahdollistettua tai edellytettyä toimintaa erotuksena omaehtoisesta. Kohteena oleminen ei koske pelkästään kertojaa yksilönä, sillä passiivimuoto liittää tämäntyyppisen kokemuksen poliittiseen kulttuuriin.

Myöhemmin haastattelussa Seppo lisää kertomukseen vaihtoehdon toisten mahdollistamalle passiiviselle osallistumiselle. Hänen osallistumisensa yhteiskunnalliseen toimintaan ja alansa seuraamiseen on omaehtoista, koska osallistumisesta voisi myös kieltäytyä eli siltä "vois sulukia silmänsä" (ote 8). Kertoja ei siis ole pelkästään passiivinen objekti ottaessaan tehtäviä ja kehityshaasteita vastaan, koska hänellä on myös mahdollisuus kieltäytyä ja valita tekemisensä.

Kertojat eivät yhdistä itsensä kehittämistä spontaanisti muodolliseen koulutukseen vaan liittävät koulutuksen itsensä kehittämiseen vasta kysyttäessä. Koulutuksen piirissä kehitytään usein yhteisön vaatimuksesta. Ammatin ja työnantajan edellyttämien uusien taitojen ja tietojen opettelu on eräs tapa kehittyä ilman omaa valintaa. Jos kertoja tekee opettelusta itselleen tärkeää ja omaehtoista, toiminnan merkitys muuttuu tietoiseksi itsensä kehittämiseksi. Seppo on tehnyt itselleen tärkeäksi asiaksi alansa muutosten seuraamisen, koska on kiinnostunut alasta ja haluaa olla mukana parantamassa liikelaitoksen toimintaa. Hän seuraa myös yhteiskunnallisia tilanteita ja osallistuu seuratoimintaan, koska saa varmuutta siitä, että tietää yhteiskunnassa tapahtuvista muutoksista. Valitessaan mukana olemisen ja kiinnostuksen kertoja asemoituu lopulta toisten tukeman kolmanteen tarinatyyppiin eli valintojen tekijän tarinaan.

Ote 8: (...) kiinnostuneisuus esimerkiks siihen, että... että nähä niinku ite esimerkiksi tärkeeksi se, että mejän tulee yrittää kehittää tätä (...) kuviota ja toimintaa ja olla (...) niinku terävänä tässä jutussa, että siinä vois sulukia sili- mänsä ja sanoa, että eihän tässä oo mitään tapahtunu kahteenkymmeneen vuoteen eikä tuu tapahtuun ja sillä siisti. (...) Se riippuu kyllä se niinku ihmisestä riippuu, että (...) tahotaanko olla siinä mukana niisä jutuisa vai ei. (Seppo)

Kertomuksissa jatkuvan oppimisen periaate näyttäytyy lähinnä yleisenä kiinnostuksena työhön. Sepolle jatkuva oppiminen ei merkitse säännöllistä kursseilla käymistä vaan vaikkapa keskusteluja kollegoiden kanssa. Henrin kertomuksissa jatkuva oppiminen merkitsee esimerkiksi luennolta tai kirjasta saatua uutta näkökulmaa johonkin asiaan tai oivallusta omasta itsestä. Mirvisin (2008) mukaan kertomusten jakaminen ja peilaaminen toisten kertomuksiin auttaa johtajia tunnistamaan oman toiminnan pinttyneitä kuvioita. Toisten kertomuksista voikin löytää omien kertomustensa rakentamiseen valinnanmahdollisuuksia, joita ei ehkä itse olisi tullut ajatelleeksi.

Toisten tukeman tarinatyyppi tukee narratiivisen tutkimustavan perusoletusta, että henkilökohtaiset kertomukset eivät koskaan ole pelkästään yksityisiä (ks. esim. Ihanus 1999; Parker 2005). Henrin ja Sepon kertomuksissa toiset ihmiset ovat usein merkityksellisiä sivuhenkilöitä, jotka pitävät huolta, neuvovat ja kannustavat sekä muistuttavat oman osaamisen rajoista.

Toisten tukeman tarinassa subjektiiviseen kehittymiseen rakennetaan selkeä transsubjektiivinen elementti. Itsensä kehittäminen ei ole narsistista, itseenkäpertyvää minuuden etsintää vaan Giddensin (1990) ehdottamalla tavalla toisia kohti avautuvia kasvupyrkimyksiä, joilla on syvä perusta tarpeessa kokea ontologista turvallisuutta ja luottamusta toisiin ihmisiin. Itseä kehittävä tekeminen ei suuntaudu vain itseen vaan myös itsen ulkopuolelle, josta siihen myös vaikutetaan. Itsensä kehittäminen ei ole toiminnan itsetarkoitus. Se saattaa kuitenkin tulla osaksi kertomusta, jos kertoja astuu lopussa ulos toisten tukeman tarinasta ja asemoituu valintojen tekijän tarinaan.

\section{Valintojen tekijän tarina}

Kuten edellä tulkittiin, itsensä kehittäminen vaatii kertojan, joka kokoaa kertomuksen ja kertoo kehityksen tapahtuneen. Selviytyjän ja toisten tukeman tarinoissa kertojat ovat sosiaalisia toimijoita, kun valintojen tekijän tarinan kertojan voi ajatella 
edustavan ihmisen tietoista ajattelua. Kahdessa ensimmäisessä tarinatyypissä kertoja saa aineksia kehittymiseensä, mutta varsinainen itsensä kehittäminen kerrotaan valintojen tekijän tarinassa. Tässä mielessä tutkimuksen keskiössä ovat etenkin kertomukset, joiden tarinatyyppi on valintojen tekijän tarina. Tutkimuksen tärkeiksi kysymyksiksi nousevatkin, millainen kertoja valintojen tekijä on sekä miksi kehittyminen on tavoiteltavaa ja mitä kohti se suuntautuu. Otesarja 9-14, jossa otteet ovat kronologisessa järjestyksessä, valaisee itseään kehittävän kertojan muotoutumista.

Ote 9: Vaikea nuoruuden koti oli, oli semmonen semmonen ympäristö, joka ajo mut kirjastoon ja etsimään sellasia vaihtoehtoja.

Ote 10: Joo en mä en todellakaan juossu kirjastossa hakemassa sillä tavalla niinkun ratkaisuja elämään, vaan ne, ne löytyi sillä... sillä sillä tota kirjaston lukemisella, et totta kai alle kymmenen vuotiaana niin sieltä etsitään Viisikko, Viisikko-kirjat ja (...) mennään seikkailukirjojen kautta ja sit tulee elämänkertoja ja ja sit sattuu käteen joku tämmönen...

Ote 11: Haastattelija: (...) missä vaiheessa sun elämää sitte aloit lukemaan toisella tavalla?

No siinä siinä vaiheessa, siinä vaiheessa $k u$ ensimmäiset semmoset havainnolliset tuli tuli eteen.

Ote 12: Haastattelija: Miten sie sitte aikusena löysit nämä tai sitte vanhempana?

Ihan systemaattisesti menemällä Akateemiseen ja Suomalaiseen kirjakauppaan. Emmä tiedä, ennen kaikkea mä löysin ne kyllä jo aiemmin sitte, no siihen aikaan ei ollu mitään amazon comeja niin niin, Lontoon kirjakaupat ja New Yorkin kirjakaupat, et mä tulin mat-, mä varasin yhden matkalaukun kirjoja varten, et et mä tulin ylipainoa mukanani Finskin koneella, että et sieltä se alko ku ei sitä niinku suomen kielelle käännettynä ollu.

Ote 13: Itse asiassa kirjojen, kirjojen niinku hankkiminen ulkomailta lähti siitä, siitä ku mä mä halusin saattaa esiintymistaidot niinkun parhaalle mahdolliselle tasolle.

Ote 14: Mä hain niitä arkkitehtuureja, tutkin arkkitehtuurit, menestyvien esitysten ja puheiden arkkitehtuurit, sitä mä kaivoin maailmalta. (Henri)

Alussa kertoja yrittää tulla toimeen elämässään, mistä kertovat passiivisuutta tai kohteena olemista kuvaavat teon sanat. Selviytyjä ei valitse itse vaan hänet ajetaan etsimään. Kertoja kuitenkin muuttaa asemointiaan kertomalla kertomustaan uudelleen. Valintojen tekijä näyttäytyy kertoessaan, ettei yrittänyt etsiä ratkaisuja. Välillä toisten tukema jatkaa löytämistä, selviytyjän käteen sattuu kirjoja tai niitä tulee hänen eteensä. Lopulta valintojen tekijä ottaa kertojan paikan tekemällä asiat tarkoituksella ja tiedostetusti varaamalla, haluamalla, hakemalla, tutkimalla ja kaivamalla-systemaattisesti.

Itsensä kehittämisellä on kuitenkin rajansa, jotka ihmisyys asettaa (otteet 15-16).

Ote 15: Kun ajatellaan elämänkaarta, niin ihmisellä on erilaiset prioriteetin viiskyt viiskytvuotiaana ku sillon kakskytvuotiaana et... Mut se ihminen itse, joka siellä siellä niinkun sisällä on ja ohjaa näitä niin sehän ei juurikaan muutu. (Henri)

Ote 16: Niinku mä sanoin että työ ei oo ainoastaan elämää, (...) ja tää on niinku täsä maailmankaikkeuesa tää on (napsauttaa sormiaan) naps tämä. Ja nyt Euroopasa ja maailmasa ja Euroopasa varsinkin niin luullaan, että me tuota, luultiin, että vuoteen kakstuhatta mennessä me ollaan saatu maailma valamiiksi ja nyt että kakstuhattakymmenen me saahaan tää valamiiksi. Ihan hulluutta, eihän me mitään saaha valamiiksi. (Seppo)

Samalla kun Seppo ja Henri kertovat tekemisen ja ymmärtämisen muutoksistaan, he pitävät itseään kutakuinkin samanlaisina ihmisinä ja johtajina kuin ennenkin. Kokemus pysyvyydestä - ei toiminnallisena tai tajunnallisena muuttumattomuutena, vaan perusihmisyytenä - kattaa kertojan historian ja siirtyy käsityksenä koskemaan suurta tarinaa: ihmiskunnan historiaa ja tulevaisuutta. Tässä suuressa tarinassa kunkin mahdollisuudet ovat lopulta rajalliset ja valmiiksi saattaminen on aina väliaikainen ratkaisu.

Miksi itsensä kehittäminen sitten on merkityksellistä? Valintojen tekijän tarinan kertojalle itsensä kehittäminen merkitsee vastuullisuutta, joka tuo hänelle vapautta päättää kertomuksensa juonen kulusta. Tämä ei tarkoita, että kertoja olisi kaikkivoipa agentti, joka voisi kertomalla muuttaa kaiken haluamakseen. Vaikka asioiden keskeneräisyys ja toimintamahdollisuuksien rajallisuus on hyväksyttävä, valintojen tekijä pyrkii kertomuksellisen 
järjestyksen luomiseen. Tämä peilautuu von Krosigkin (2007) huomioon, jonka mukaan intoleranssi kaoottisuutta kohtaan sekä halu luoda ja ylläpitää järjestystä on tyypillistä ja motivoivaa tehokkaille johtajille.

Kertomus itsensä kehittämisestä ei pysähdy kertojan omaan muutokseen. Seppo ja Henri kertovat tärkeäksi sen, että voivat osallistua oman työyhteisön, toisten työyhteisöjen ja kotiseudun hyvinvoinnin edistämiseen esimerkiksi kouluttamalla ja sponsoroimalla. Valintojen tekijän tarinassa kertoja haluaa jakaa oppimiaan asioita yhteisölle, jossa hän on oppinut. Oppimisen jakamisen voi nähdä kertomuksen uudelleenkerrontana tai edelleenkerrontana, joka mahdollistaa jaetun tarinaperinteen uusintamisen ja rikastamisen. Kertoja paitsi kertoo omaa kertomustaan myös rakentaa yhteistä tarinaa.

Ennen pohdintaosuutta on hyvä palata lyhyesti tutkimuksen peruskäsitteeseen. Mikä itse on ja mikä itseä kehitettäessä kehittyy? Csikszentmihalyi (2006) esittää psyykkisen itsen muodostuvan siitä, mihin ihminen kohdistaa tarkkaavaisuutta ja miten hän sen tekee. Tällä hän tarkoittaa esimerkiksi, että asioita valoisasti katsovasta tulee myönteinen ihminen ja päinvastoin. Hän myös kuvaa tavoitteita välineiksi, joilla tarkkaavaisuuden kohde ja psyykkisen energian suunta valitaan. Kun tämä tulkitaan narratiivisin käsittein, voidaan ajatella, että itse on kertoja, joka muokkautuu valintojensa kautta. Itsensä kehittäminen voi olla henkiseen kasvuun tähtäävää toimintaa, mutta ennen muuta se on nykyhetkessä tapahtuvaa, aktiivista itsen määrittelyä. Valintojen tekijä luo itsensä kertomalla.

\section{Tietoisesti kertomalla kohti uutta}

Itsensä kehittämisen merkityksissä yksilöllinen valinnanvapaus ja omaehtoinen, autonominen kehittyminen nivoutuvat yhteisölliseen elämään. Ihminen on yksilöllisyydestään huolimatta yhteisöllinen olio, joka tarvitsee elinympäristöään oppiakseen ja saadakseen mahdollisuuksia valintojen tekemiseen (Bargh 2004). Valintojen elämäntilanteelliset sidokset eivät tee valinnoista epäitsenäisiä vaan ne tekevät tietoisista valinnoista yksilöllisiä. Elämäntilanne ei määrää kertojan toimintaa. Se vain tekee tietyt valinnat, ja tietyt kertomukset, mahdollisiksi ja toiset mahdottomiksi.

Perusteet autonomian toteutumiselle ovat kriit- tisiä pohdittaessa itsensä kehittämistä: millä perustein kertoja sanoo valitsevansa itse ja kertoo tekojensa olevan autonomisia? Ihminen voi luulla tekevänsä autonomisia valintoja, kun häntä ohjaavatkin tiedostamattomat elämäntilanteelliset tekijät, kuten tunteet, tarpeet ja motiivit (Ryan \& Deci 2004). Myös arjen sujuvuuden kannalta välttämättömät tavat ja rutiinit luovat toiminnalle kehyksen, joka muokkaa valintoja huomaamattomasti (Giddens 1995).

Valinnat voidaan kertoa tietoisiksi korostamalla itsereflektiota sekä omien tunteiden ja asenteiden tunnistamista (ks. esim. Kaiser \& Kaplan 2006) tai valintojen poikkeavuutta totutuista valinnoista eli tapakertomuksista. Mitä selkeämmin kertoja näkee tilanteen tarjoamat mahdollisuudet, sitä paremmin hän pystyy valitsemaan sopivat toimintavaihtoehdot ja kehittämään itseään tietoisesti. Koska abstraktien yhteiskunnallis-sosiaalisten järjestelmien tarjoamat optiot ja mahdollisuus nähdä eri vaihtoehtoja vaihtelevat yksilöiden välillä, valinnat riippuvat myös vaikutuspiirin ulottumattomissa olevista rakenteista ja heijastavat näin valtasuhteita (Giddens 1990, 1995). Itsensä kehittämisestä kertominen riippuu rakenteellisista tekijöistä, kuten työyhteisöaseman tuomista edellytyksistä.

Johtamiskirjallisuudessa johtajuuden kontekstina nähdään usein myöhäismoderni yhteiskunta, jossa ihmisen kerrotaan menettäneen kokemuksensa todellisesta itsestään ja ajallisesta jatkuvuudesta - hänen minuutensa kerrotaan jopa pirstaloituneen (esim. Juuti 2001; Siltala 2002). Työelämän todellisuutta luodaan tässä diskurssissa epäluonnolliseksi, kiireiseksi ja oikukkaaksi. Tutkituissa johtajien kertomuksissa kertoja ei kuitenkaan ollut elämän sattumien ja valinnanmahdollisuuksiensa keskellä hajanainen tempoilija. Sen sijaan kertoja oli koherentti toimija, joka rakensi itsestään ajallisesti jatkuvaa, omia valintojaan toteuttavaa persoonaa.

Åhmanin (2003) tutkimuksenkaan perusteella myöhäismodernius ei aiheuta identiteetin hajoamista työyhteisöissä vaan ennemmin yhteisöllisen yksilöllisyyden arvostamista. Tällainen ajankuva piirtyy myös tästä tutkimuksesta. Itsensä kehittäminen ei ole pirstaleisen minuuden pakonomaista hallintaa vaan aktiivista, sopeutumista edistävää minuuden rakentamista (ks. Giddens 1990). Minuuden pirstaloituminen lienee ajassamme mahdollista, muttei väistämätöntä. Ehkä juuri kertominen on keino pitää minuus koossa. Kun 
paikallinen traditio tai yhteinen tarina ei enää anna kiinteää ankkuripaikkaa identiteetille (Giddens 1995), minuus koostetaan monitahoista maailmaa jäsentävien kertomusten avulla.

Itsensä kehittäminen ei rajoitu vain formaaleihin oppimistilanteisiin vaan sen rajat ovat samat kuin ihmisenä kehittymisen: koettu elämä kaikkinensa vaikuttaa johtajan - ja johtajaksi - kehittymiseen (Von Krosigk 2007). Aikuiskasvatuksen näkökulmasta johtajakoulutuksessa olisikin otettava huomioon johtajien erilaisten elämäntilanteiden ja -kokemusten tuomat mahdollisuudet sekä käytettävä niitä oppimisen potentiaaleina. Koulutuksen olisi paitsi linkityttävä työkäytäntöihin myös annettava johtajille menetelmiä, jotka auttavat jatkuvaa itsensä kehittämistä ja edistävät oppivaa johtamista (ks. Antonacopolou \& Bento 2004).

Tutkimuksen perusteella johtajan itsensä kehittämisen teemasta rakentuu tarina, joka vaikuttaa hyvinkin tutulta. Ikiaikaisten ihmisen kehittymisestä kertovien tarinoiden käsitteet ovat muuttaneet muotoaan, mutteivät niinkään sisältöään. Yhä vielä johtaja kehittyy, kun hiljentyy kuuntelemaan sisintään ja huomioi teoissaan myös muiden hyvinvoinnin (Heider 1998). Käsitellyt kertomukset ovat nykyjohtajien muunnelmia tarinasta, jossa ihminen elämän läpi kulkiessaan tulee yhä enemmän yhteisönsä jäseneksi ja samalla yhä enemmän omaksi itsekseen.

Narratiivinen lähestymistapa osoittautui mielekkääksi tavaksi ymmärtää itsensä kehittämistä humanistista traditiota laveammin. Narratiivinen lähestymistapa sitoi johtajien itsensä kehittämisen kertomuksiksi, joissa ovat läsnä humanistinen itseksi tuleminen, eksistentiaalinen persoonan valitseminen ja kulturalistinen jaetuissa merkityksissä eläminen.

On kiinnostavaa, että kertomukset johtajien itsensä kehittämisestä eivät päästäneet irti siitä ideaalista, jota humanistinen ihmiskäsitys itseksi kehittymisestä rakentaa. Joko johtajissa - ja samalla kaikissa aikuisissa - on olemus, jota seuraten he tulevat enemmän itsekseen, tai sitten humanismi on myöhäismodernissa suomalaisessa yhteiskunnassa yhä tärkeä kulttuurinen juonne, joka jatkaa elämäänsä, jos ei muualla, niin kulttuurimme itseä koskevissa kertomuksissa. Mahdollista on myös se, että molemmat selitykset ovat tosia, omaksutusta ihmiskäsityksestä totuutensa ammentaen.

\section{Lähteet}

Aaltonen, M. \& Heikkilä, T. (2003). Tarinoiden voima: miten yritykset hyödyntävät tarinoita? Helsinki: Talentum.

Antonacopolou, E. \& Bento, R. (2004). Methods of 'learning leadership': taught and experiental. Teoksessa J. Storey (toim.), Leadership in organizations: current issues and key trends (s. 81-102). Lontoo: Routledge.

Bargh, J. (2004). Being here now: is conciousness necessary for human freedom? Teoksessa J. Greenberg, S. Koole, \& T. Pyszczynski (toim.), Handbook of experimental existential psychology (s. 385-397). New York: The Guilford Press.

Bruner, J. (1990). Acts of meaning. Cambridge: Harvard University Press.

Carden, L. \& Callahan, J. (2007). Creating leaders or loyalists? Conflicting identities in a leadership development programme. Human Resource Development International 10(2), 169-186.

Csikszentmihalyi, M. (2006). Kehittyvä minuus: visioita kolmannelle vuosituhannelle. Helsinki: Rasalas.

Erkkilä, R. (2005). Moniääninen paikka-opettajien kertomuksia elämästä ja koulutyöstä Lapissa. Oulu: Yliopistopaino.

Gadamer, H.-G. (2004). Hermeneutiikka: ymmärtäminen tieteissä ja filosofiassa. Tampere: Vastapaino.

Giddens, A. (1990). The consequences of modernity. Stanford: Stanford University Press.

Giddens, A. (1995). Elämää jälkitraditionaalisessa yhteiskunnassa. Teoksessa U. Beck, A. Giddens \& S. Lash (toim.), Nykyajan jäljillä: refleksiivinen modernisaatio (s. 83-152). Tampere: Vastapaino.

Heider, J. (1998). Johtamisen tao: uuden aikakauden johtamisstrategioita. Helsinki: Unio Mystica.

Hyvärinen, M. (2004). Eletty ja kerrottu kertomus. Sosiologia , 4, 297-309.

Hyvärinen, M. (2006). Kerronnallinen tutkimus [verkkojulkaisu]. <http://www.hyvarinen.info/ material/HyvarinenKerronnallinen_tutkimus.pdf $>$. (Haettu 28.1.2009.) 
Ihanus, J. (1999). Minäkertomukset. Teoksessa J. Ihanus (toim.), Kulttuuri ja psykologia (s. 241-259). Helsinki: Yliopistopaino.

Janson, A. \& McQueen, R. (2007). Capturing leadership tacit knowledge in conversations with leaders. Leadership \& Organization Development Journal, 28(7), 646-663.

Joiner, B. \& Josephs, S. (2007). Developing agile leaders. Industrial \& Commercial Training, 39(1), 35-42.

Juuti, P. (2001). Johtamispuhe. Jyväskylä: PSkustannus.

Juuti, P. (2005). Toivon johtaminen. Helsinki: Otava.

Kaiser, R. \& Kaplan, R. (2006). The deeper work of executive development: outgrowing sensitivities. Academy of Management Learning \& Education 5(4), 463-483.

Kannisto, H. (1994). Ihminen ja normatiivinen järjestys: ehdotus filosofisten ihmiskäsitysten typologiaksi. Teoksessa T. Laine (toim.) I $h m i$ sen mallit. Symposiumi filosofisesta antropologiasta (s. 10-29). Jyväskylän yliopisto, filosofian laitos, julkaisu 62.

Mirvis, P. (2008). Executive development through consciousness-raising experiences. Academy of Management Learning \& Education 7(2), 173-188.

Murray, M. (2004). Narrative psychology. Teoksessa J. Smith (toim.), Qualitative psychology: a practical guide to research methods (s. 111-131). London: Sage.

Neck, C. \& Houghton, J. (2006). Two decades of self-leadership theory and research: past developments, present trends, and future possibilities. Journal of Managerial Psychology, 21(4), 270-295.

Olivares, O., Peterson, G. \& Hess, K. (2007). An existential-phenomenological framework for understanding leadership development experiences. Leadership \& Organization Development Journal, 28(1), 76-91.

Parker, I. (2005). Qualitative psychology: introducing radical research. Maidenhead: Open University Press.

Perttula, J. (2006). Johtaminen psykologisena ihmistyönä. Hallinnon Tutkimus, 25(4), 74-76.

Perttula, J. (2009). Persoonallisuus ihmiseksi tulemisena. Teoksessa R-L. Metsäpelto \& T.
Feldt (toim.), Meitä on moneksi. Persoonallisuuden psykologiset perusteet (s. 195-212). Jyväskylä: PS-kustannus.

Ricœur, P. (1997). From text to action: essays in hermeneutics, II. Evanston: Northwestern University Press.

Ricœur, P. (2005). Mimesis, viittaus ja uudelleenhahmottuminen. Teoksessa J. Tontti (toim.), Tulkinnasta toiseen: esseitä hermeneutiikasta (s. 164-174). Tampere: Vastapaino.

Ryan, R. \& Deci, E. (2004). Autonomy is no illusion: self-determination theory and the empirical study of authenticity, awareness, and will. Teoksessa J. Greenberg, S. Koole \& T. Pyszczynski (toim.), Handbook of experimental existential psychology (s. 449-479). New York: The Guilford Press.

Saarinen, M. \& Aalto-Setälä, P. (2007). Perkele: tunneosaamisen oppikirja esimiehille. Helsinki: Kirjapaja.

Salojärvi, S. (2006). Nousevatko osaajat entistä suurempaan arvoon? Teoksessa P. Juuti (toim.), Johtaminen eilen, tänään, huomenna (s. 168-177). Helsinki: Otava.

Siltala, H. (2002). Johtamalla eettisyyteen - hyvään elämään. Teoksessa P. Juuti (toim.), Ethosta etsimässä (s. 119-131). Jyväskylä: PSkustannus.

Syväjärvi, A., Perttula, J., Stenvall, J., Majoinen, K. \& Vakkala, H. (2007). Psykologisen johtamisen haaste kompleksisessa muutostilanteessa ja ihmisen muutosdynamiikassa. Hallinnon Tutkimus, 26(3), 3-17.

Toskala, A. (2000). Itsetuntemus ja johtajuus II: Järjen ja tunteen vuoropuhelua. Jyväskylä: Odeco.

Von Krosigk, B. (2007). A holistic exploration of leadership development. South African Journal of Business Management 38(2), 25-31.

Åhman, H. (2003). Oman mielen johtaminen: $n \ddot{a}-$ kemyksiä ja kokemuksia yksilön menestymisestä postmodernissa organisaatiossa. Espoo: Teknillinen korkeakoulu.

\section{Viite}

Virpi Tökkärin hallintotieteen, erityisesti johtamisen psykologian, pro gradu -tutkielma (2008). 